Vol. XXIII No $1 \quad 2017$

\title{
THE VICIOUS CIRCLE OF SUBSIDISED EMPLOYMENT
}

\author{
Boryana VARBANOVA \\ "Vasil Levski" National Military University, Veliko Tarnovo, Bulgaria \\ varbanova_01@abv.bg
}

\begin{abstract}
The problem with subsidised employment has become more and more serious in recent years. There is a trend in which vulnerable groups lose their jobs again after the period of support. Our focus in this report is on employment and, in particular, on the issues related to its effective and not so effective stimulation. When implementing this strategy in Bulgaria, institutions aim primarily at reaching certain numeric indicators, rather than structural reforms and discontinuation of bad practices.
\end{abstract}

\section{Keywords: employment, subsidised, vulnerable groups, job}

\section{Introduction}

The ten-year growth strategy Europe 2020 of the European Union aims to create conditions for "a smart, sustainable and inclusive growth in the EU" [1]. The National Employment Action Plan for 2017 is a mechanism for adjusting the labour market towards sustainability, balance and better performance [3]. The aim is to support a favourable employment growth in economy, to balance the labour market by training personnel for jobs and in professional fields with unsecured demand. Moreover, there is a desire for activation of inactive individuals and proactive workforce training for the increasing demand from businesses and a successful adaptation of the economy to external and internal challenges of economic development. The implementation of the Plan supports the achievement of the objectives and the commitments of the country in the implementation of the EU Strategy 2020, as well as the measures included in the National Reform Programme 2016 - 2020, the Convergence Programme 2017 - 2020 [6], the tasks of the Updated Employment Strategy 2013 - 2020, the
National Youth Guarantee Implementation Plan 2014 - 2020 (Figure 4), the National Strategy for Lifelong Learning, the National Strategy for People with Disabilities 2016 2020, the National Development Programme: Bulgaria 2020, etc.

\section{Key issues}

The strategy Europe 2020 focuses on three areas - employment, education and poverty. Studies show that in Bulgaria this relationship is most pronounced, and almost half of the population with low education level is at risk of poverty. Low education is a major prerequisite for unemployment the employment rate for people with primary education is below $30 \%$, while for university graduates it is more than $80 \%$ $[2,5]$.

The object of interest in this report is to study employment, and more specifically, the problems associated with its inefficient stimulation. The following key issues stand out:

- the first and foremost goal is to spend the provided money without seeking efficiency of its use; 
- there is no evidence that the market is recovering exactly because of the implementation of the action plans in previous years;

- inappropriate target groups are chosen the main target groups are again the least vulnerable. The plan says that "employers want to hire young people the most and that is why the focus is on young people" [4] (Figure 1). In this statement there is a serious contradiction. Support programmes should not be aimed at people who will be employed anyway. Thus, many employers hire people with the sole purpose of draining funds.

The trend is almost all programmes and resources to be focused on subsidised employment. In the previous year, about $85 \%$ of the funds were for direct job creation, and the rest - for passive measures and training. Data from recent years show that subsidised employment does not have a long-term influence on both the labour market and on the people who participate in it (i.e. when the programme is over, these people are again unemployed). In developed economies, direct job creation has long been displaced by passive measures. In 2016, in other EU countries, about $17 \%$ of the funds from policies for stimulation of the labour market were allotted for direct job creation on average, and in Bulgaria - $89 \%$ (according to Eurostat data, Fig. 2), which comprises the largest share in the EU. Moreover - only in Hungary and Bulgaria the share of these funds is over $50 \%$, and in more than half of the countries - below $10 \%$.

\section{Opportunities to improve the} effectiveness of subsidised employment.

It is a kind of progress that the most expensive and most ineffective programme over the past 10 years, i.e. From Social Assistance to Employment, dropped in 2016. The reason is that an evaluation of the effect of the programmes was performed, and it showed that tremendous resources are used without any effects on the labour market.

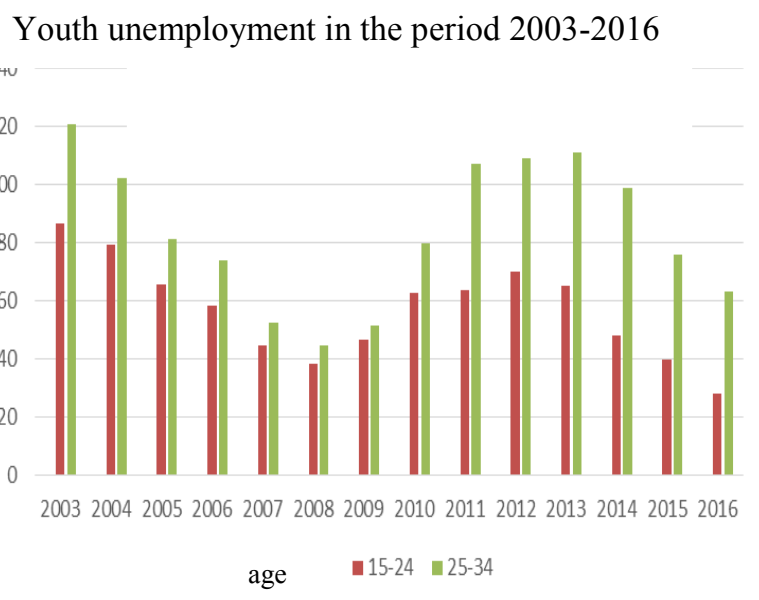

Figure 1 Youth unemployment for the period 2003-2016

Eurostat data show that young people (under 29 years) with higher education are the most successful in finding a job after the employment programme. Over $65 \%$ of them were employed one year after the programme. It is clear that the higher qualification and education give better opportunities in the labour market. It is also expected that the businesses will take advantage of the programme to save costs when they need staff. This explains why a great number of those who took part in the programme are able to actively participate in the labour market after completing it. The analyses show that most people in this particular group continued working for the same company after completion of the employment programme [6].

At the same time, the least success in subsequent employment is shown by people who benefited from the largest programmes From Social Assistance to Employment and Assistants to the Disabled - respectively $13.4 \%$ and $15.6 \%$ of the people who benefited from programmes had found a job when a check was performed one year after the programme. Those programmes include mainly people from vulnerable groups in the labour market - long-term unemployed, people with disabilities, and young people 
from social institutions. These results are most indicative of the failure of active policies on the labour market.

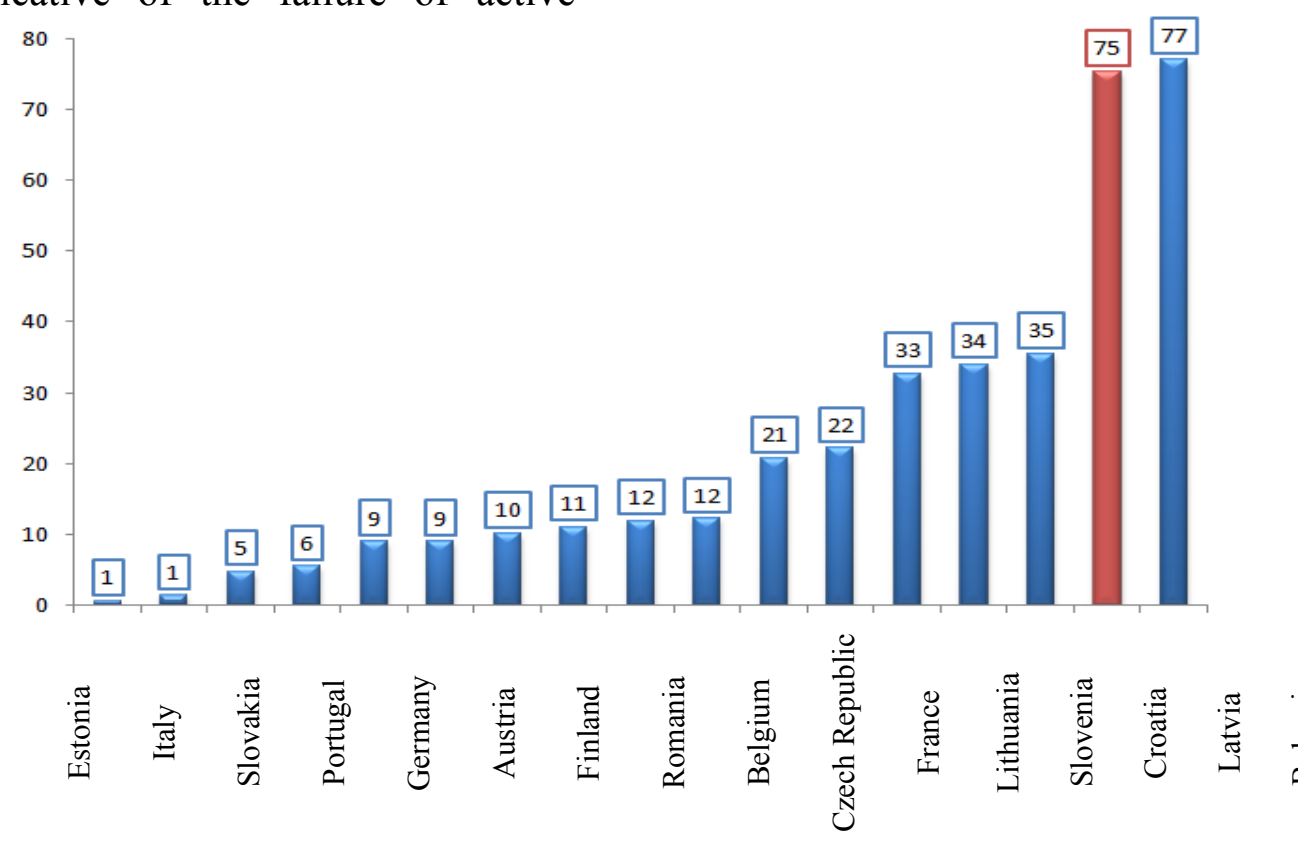

Figure 2 Share of expenditures for direct job creation by the total cost of the policies of the labour market in 2016, \% (Source: Eurostat data, calculations of the Institute for Market Economics)

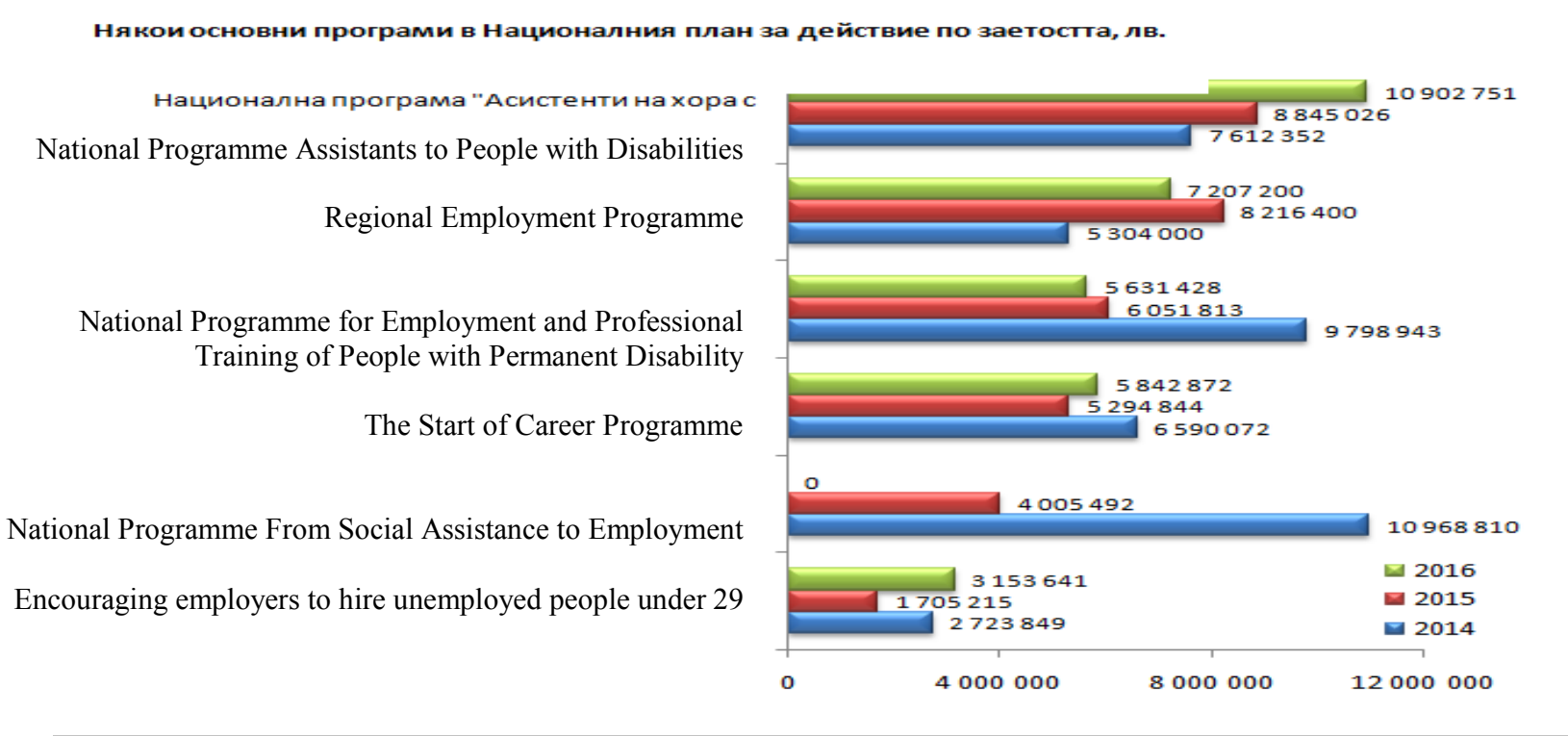

Figure 3 Main programmes in the National Employment Action Plan for 2016 in levs

Given that the active measures comprise less than $6 \%$ of the unemployed (Figure 3 ) in an environment of scarcity of resources, efforts should be geared towards the most vulnerable groups - unskilled, long-term unemployed, people with disabilities. It turns out that subsidised employment fails at this point.

Hiring those unemployed for several months is quite a short-term solution and does not lead to any lasting positive effects. On the other hand, the longer these people are outside the labour market, the more difficult their reintegration is (Figure 4). Released data show that this year the policies of the labour market will continue to be implemented under the old scheme. The state will subsidise employment with priority and will take account of the costs without actually increasing the chances of 
vulnerable groups to be employed longterm or to create a more favourable business environment for the opening of new jobs in the real sector. Analyses and intentions can only be found in documents. The practical implementation of the policy is done in the old, flawed way. The European Commission with the Council Recommendation on the integration of the long-term unemployed into the labour market gave prescriptions (in September 2016) according to which the attempts to boost employment and competitiveness of the unemployed and inactive persons are to be carried out through guidance, counselling, training, qualification and retraining. The recommendation is mentioned in the National Employment Action Plan for 2016, but this year the attention seems to focus again on the well-known employment programmes.

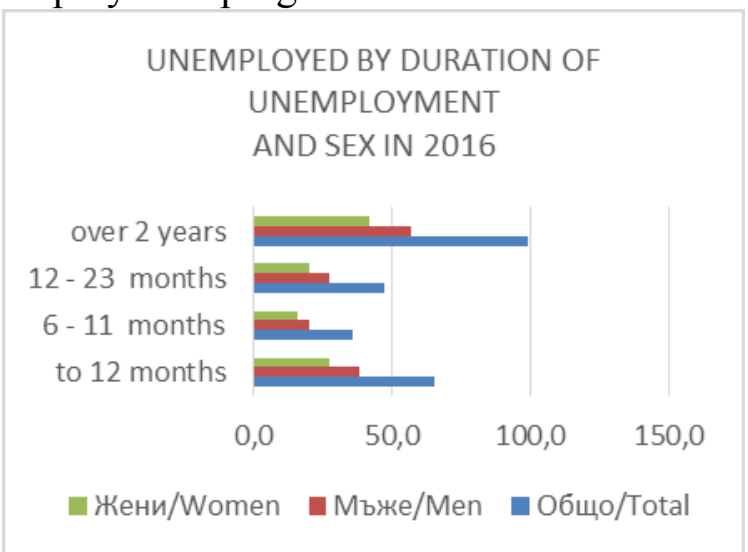

Figure 4 Unemployed people by duration of unemployment [6].

\section{Conclusions and recommendations.}

The continuous implementation of an active policy in terms of unemployment through subsidised employment creates conditions for falling into a vicious circle of people constantly expecting this type of programmes without having a real opportunity in the labour market in the absence of government support. While in most EU countries the focus is on a passive policy which creates knowledge and skills among the unemployed, thus leading them to realisation after the end of the programme, which they are part of,
Bulgaria relies heavily on direct job creation.

The majority of the jobs, however, are created in the real sector, and until the economic environment is improved, there cannot be any significant results. Again we witness the spending of millions on taking ineffective actions in a sector without addressing the root of the problem. In the absence of interest to undertake long-term policies, the unemployment problem (as well as other pressing issues) gets only a superficial solution for a short period.

It turns out that most programmes are aimed more at stimulating businesses, rather than at the permanent opening of new jobs. This is so, because businesses have the opportunity to take advantage of cheap or even free employees for a certain period of time.

In the majority of cases these programmes are targeted at low-skilled persons (longterm unemployed, less educated, Roma, persons with disabilities and other vulnerable groups). Despite the occasional success in terms of increasing the number and proportion of people who have managed to return to the primary labour market after participating in some of the programmes, the, continuing in 2017 growth of long-term unemployed and the deepening structural unemployment testify for the low efficiency of such a policy.

To overcome these problems it is necessary to abandon the universal approach in determining the benefits and privileges. We consider it appropriate to limit the number of times to participate in employment programmes, which will enable more people to benefit from them.

In order to avoid abuse, persons not taking the jobs offered by the labour offices or unwilling to participate in those programmes, shall be added to the category of "not working" rather than unemployed.

The gradual expansion of the measures covered by the Operational Programme "Human Resources Development" (OPHRD) implies gradual shifting of a 
larger percentage of funds towards training activities, counselling and initiatives to increase the workers' incentives to look for employment. The main prerequisites for the success of such restructuring appear to be the creation of the administrative capacity needed for the implementation of programmes in these areas and the accumulation of practice and experience in managing Europe's funds.

[1] Strategy Europe 2020

\section{References}

[2] "Council Recommendation on Bulgaria's 2013 National Reform Programme and Delivering a Council Opinion on Bulgaria's Convergence Programme for 2012-2016", COM (2013) 352 final, p. 5, para. 13

[3] National Employment Action Plan for 2017

[4] http://ime.bg/bg/articles/i-prez-2016-dyrjavata-zalaga-na-subsidirana-zaetost-v-borbatas-bezraboticata/ - 04.04.2017 г.

[5] http://ime.bg/bg/articles/uspeshni-li-sa-aktivnite-merki-na-pazara-na-truda/

[6] http://www.nsi.bg/ 